\title{
Effect of genotype resistance and fungicide rates on fusarium wilt incidence of chickpea
}

\begin{abstract}
Fusarium wilt caused by Fusarium oxysporum f. sp. ciceris is a soil and seed borne disease affecting chickpea which is widely distributed where chickpea is grown. It causes yield losses in the range of 12 to $100 \%$ depending on the level of resistance of the genotype and suitability of environmental conditions for disease development. Management of soil borne diseases mainly involves use of preventive measures because it is harder to control the disease once established. Host plant resistance is frequently used in conjunction with fungicidal seed treatment in managing diseases of this nature. Thiram and carbendazim are used in majority of the crops as seed dress fungicides against a wide variety of pathogens. The efficacy of the rates of these two fungicides against Fusarium wilt of chickpea were evaluated at four levels $(0 \%, 50 \%$, $100 \%$ and $150 \%$ ) of the recommended rate for each $(1.5 \mathrm{~g} / \mathrm{Kg}$ seed $)$; in the field in a split plot arrangement. Two varieties, Chania 1 which is moderately resistant and Chania 2 which is highly susceptible were used in the study. Lower wilt incidences were observed in moderately resistant Chania 1. The best Fusarium wilt management was observed with $150 \%$ rate for either fungicide at all growth stages. There were significant interactions between fungicide treatments and variety (resistance), leading to lower wilt incidence in moderately resistant Chania 1 variety at low fungicide rates.
\end{abstract}

Volume 5 Issue 5 - 2016

\author{
Kirui KR,' Kibe AM,' Wagara IN, ${ }^{2}$ Thagana \\ $M W^{3}$ \\ 'Department of crops, horticulture and soils, Egerton University, \\ Kenya \\ ${ }^{2}$ Department of Biological Sciences, Egerton University, Kenya \\ ${ }^{3}$ Department of Agricultural sciences \& Technology, Kenyatta \\ University, Kenya
}

Correspondence: Kirui KR, Department of crops, horticulture and soils, Egerton University, Kenya,

Email ricksonkirui@hotmail.com

Received: April 17,2016 | Published: December 28, 2016

\section{Introduction}

Chickpea (Cicer arietinum L.) is an important cool season food legume crop mainly grown in dry areas with residual soil moisture and has great agronomic potential for use as food grain, salad, snacks and forage in dry land areas of Kenya. ${ }^{1-3}$ It is a hardy crop that grows in dry land areas and yields substantially well. Preliminary studies in Naivasha show potential yields of between 1.6 and 2.3 tons of grain per hectare for cultivars ICCV 95423 (Kabuli) and ICCV 97105 (Desi), respectively ${ }^{4}$ at varying plant population densities and Nitrogen levels. ${ }^{5}$ Serious pests and diseases affecting the chickpea crop at various growth stages however limit its' productivity. Generally, the pathogens that affect chickpea crop include fungi, bacteria, viruses and mycoplasma. Fungal pathogens affecting roots, stems, leaves, flowers and pods comprise the most serious group of pathogens of chickpea. The important diseases are Ascochyta blight, Fusarium wilt, Dry root rot, Stunt, Botrytis gray mould, Collar rot, Black root rot, Phytophthora root rot, Pythium root and seed rot. ${ }^{6}$ The complex in which soil borne pathogens occur makes isolated control of one pathogen difficult and therefore necessitates combination of host plant resistance together with fungicidal seed treatment strategies and other cultural practices like crop rotation. Chickpea is a new crop in Kenya which is still under yield performance trials with the aim of seed bulking in the Rift Valley before adoption by farmers. Several lines that have been found to yield well across several environments need to be evaluated further for drought tolerance and resistance to pests and diseases.

Fusarium wilt causes varying degree of yield losses which can be as high as eighty percent depending on the level of resistance of the genotype. Fusarium wilt is the most serious root disease wherever chickpea is grown. ${ }^{7}$ Host plant resistance (resistant genotypes) is the most reliable, environmental friendly, economically affordable to small scale farmers and durable method of management of Fusarium wilt and other diseases of chickpea. To ensure durability of resistance genes, host plant resistance (HPR) is used together with other methods of control in an integrated management. Fungicidal seed treatment is frequently used in conjunction with HPR and in this case carbendazim and thiram are chemical fungicides commonly used for control of soil borne pathogens. Fungicides can only be used in a limited scale, for example as seed dress in an integrated disease management approach. ${ }^{8}$ In Kenya, these chemicals have not been exhaustively evaluated for efficacy against fusarium wilt pathogen of chickpea and also the optimal rates of these two chemicals had not been determined. Therefore, a study was conducted to determine the efficacy in application rates of carbendazim and thiram. The objectives of this study was

i. To determine the impact of host plant resistance (variety choice) on Fusarium wilt incidence,

ii. To determine the optimal rate of fungicidal seed dress application and

iii. To establish whether there was any interaction between resistance (genotype) and fungicide treatment on Fusarium wilt incidence.

\section{Material and methods}

\section{Evaluation of fungicides rates in control of Fusarium wilt in a sick plot}

The experiment was set up at Kenya Agriculture and Livestock research organization (KALRO), Njoro (Kenya); in a wilt sick plot. One moderately resistant (MR) Chania 1 and one highly susceptible (HS) variety Chania 2 was used in the experiment and two fungicides (carbendazim and thiram) at three levels; 50, 100 and $150 \%$ of ICRISAT's recommended dosage $(1.5 \mathrm{~g} / \mathrm{kg}$ seed) of each fungicide, was used. The experimental design was split-plot replicated three times in two seasons. The main plot factors were the two varieties (genotypes) of chickpea Chania 1 and Chania 2 while the sub plot 
factors were the two fungicides ( $\mathrm{Ft}$ and $\mathrm{Fc}$ ) thiram and carbendazim both at three rates of 50,100 and $150 \%$. There was a common control $(0 \%$ fungicide) as a sub plot in each main plot factor. This gave a total of seven treatment combinations (see annex for a figure). The sub plot treatments were randomized within the main plot. Weekly scoring for Fusarium wilt incidence was done on all treatment plots and the experiment was repeated in another season. A population of 250,000 plants per Ha was achieved at a spacing of $10 \mathrm{~cm} \times 40 \mathrm{~cm}$. The data was analyzed using Genstat software for ANOVA and the means were separated based on 1sd. Models were developed to illustrate relationship between disease incidence and growth stage using Ms Excel software.

\section{Results and discussion}

\section{Effect of variety on Fusarium wilt incidence (Main plot effect)}

In both seasons highly susceptible Chania 2 showed significantly $(\mathrm{P} \leq 0.05)$ higher wilt incidences ranging from $4.6 \%$ at 30 Days after Sowing (DAS) to $23.8 \%$ at $60 \mathrm{DAS}$, while moderately resistant Chania 1 had lower wilt incidences ranging from $2.6 \%$ at 30 DAS to $13.2 \%$ at 60 DAS (Table 1). Host resistance was significant in as far as wilt incidence was observed.

\section{Effect of carbendazim rates in control of Fusarium wilt of chickpea}

Fusarium wilt incidence was significantly $(\mathrm{P} \leq 0.05)$ lower in all fungicide treatments as compared to the control treatment (no fungicide). Significant $(\mathrm{P} \leq 0.05)$ differences were observed between carbendazim rates used. Treatment of chickpea with $150 \%$ carbendazim resulted in wilt incidence of $2.1 \%$ at 30 DAS, in both season I and II (Table 1). At 45 DAS, treatment of chickpea with $150 \%$ carbendazim resulted in $5.4 \%$ and $5.1 \%$ wilt incidence in season I and II, respectively. At 60 DAS, treatment plots with $150 \%$ carbendazim had wilt incidence of $9.0 \%$ and $8.3 \%$ during season I and II, respectively. Treatment of chickpea with $100 \%$ carbendazim resulted in significant $(\mathrm{P} \leq 0.05)$ difference in wilt incidence of chickpea. At $30 \mathrm{DAS}, 3.3 \%$ and $3.4 \%$ wilt incidence was observed in season I and II at $100 \%$ rate of carbendazim. At 45 DAS, $9.4 \%$ and $8.9 \%$ wilt incidence was observed in $100 \%$ carbendazim treatment, for season I and II, respectively. At 60 DAS, treatment of chickpea with $100 \%$ carbendazim resulted in wilt incidence of $18.1 \%$ and $14.5 \%$ for season I and II, respectively. Control treatment had wilt incidence of $5.6 \%$ and $5.9 \%$ in season I and II, respectively at 30 DAS. At 45 DAS, control treatment had wilt incidence of $19.9 \%$ and $19.6 \%$ in season I and II, respectively. At 60 DAS, control treatments (no fungicide) had $30.2 \%$ and $27.5 \%$ wilt incidence in seasons I and II, respectively. It was observed that significant $(\mathrm{P} \leq 0.05)$ variations occurred between carbendazim rates used in terms of management of wilt incidence. The least wilt incidence was observed when $150 \%$ of carbendazim was used, with values ranging from $2.1 \%$ to $9.0 \%$ across all the growth stages. The next best treatment was $100 \%$ carbendazim, which resulted in wilt incidence in the range of $3.3 \%$ to $18.1 \%$ across all growth stages. This was followed by treatment with $50 \%$ carbendazim which resulted in wilt incidence ranging from $4.4 \%$ to $23.1 \%$ across all growth stages. The highest wilt incidence was observed in the no fungicide treatment with incidences ranging from $5.6 \%$ to $30.2 \%$, across all growth stages. This study demonstrated that treatment of chickpea with varying rates of carbendazim significantly reduced plant mortality (lower wilt incidence) which was in agreement with studies by Maitlo et al. ${ }^{9}$ and Nikam et al. ${ }^{10}$ In vitro studies on the inhibition of $F$. oxysporum $\mathrm{f}$. $\mathrm{sp}$. ciceris by various fungicides indicate that carbendazim at varying rates is effective against this pathogen. ${ }^{9}$ Singh et al., ${ }^{11}$ also reported highest seed germination with carbendazim. Fungicide application protects the seed from soil and seed borne $F$. oxysporum f. sp. ciceris by mechanism like the eradication of the pathogen from the seed or the impact of fungicide on the inoculum in the rhizosphere.

\section{Effect of varying thiram rates in control of Fusarium wilt of chickpea}

Thiram rates had significant $(\mathrm{P} \leq 0.05)$ effects in the management of Fusarium wilt incidence $(\mathrm{P} \leq 0.05)$ at all the growth stages. Application of thiram at the rate of $150 \%$ gave the best control of Fusarium wilt incidence at 30th growth stage with wilt incidence of $1.8 \%$ in season I and II. At 45 DAS, treatment with $150 \%$ thiram resulted in 5.2\% and $4.9 \%$ wilt incidence in season I and II, respectively. At 60 DAS, thiram at $150 \%$ resulted in wilt incidence of $8.9 \%$ and $7.9 \%$ for season I and II, respectively (Table 1). Treatment of chickpea with $100 \%$ thiram resulted in wilt incidence of $3.3 \%$ at 30 DAS in both seasons. At 45 DAS, $100 \%$ treatment with thiram gave $9.0 \%$ wilt incidence and $8.8 \%$ wilt incidence in season I and II, respectively. At 60 DAS, treatment with $100 \%$ thiram gave $17.1 \%$ and $15.6 \%$ wilt incidence in season I and II, respectively. Treatment of chickpea with 50\% thiram at 30 DAS resulted in wilt incidence of $4.7 \%$ and $4.1 \%$ in season I and II, respectively. At 45 DAS, treatment of chickpea with $50 \%$ thiram resulted in $15.9 \%$ and $13.4 \%$ wilt incidence in season I and II, respectively. At 60 DAS, chickpea plots treated with 50\% thiram had wilt incidence of $22.8 \%$ and $21.3 \%$ for season I and II, respectively. Control treatment plots had wilt incidence of $5.6 \%$ and $5.9 \%$ in season I and II, respectively at 30 DAS. At 45 DAS, control treatment had wilt incidence of $19.9 \%$ and $19.6 \%$ in season I and II, respectively. At 60 DAS, control treatments had $30.2 \%$ and $27.5 \%$ wilt incidence in seasons I and II, respectively. It was apparent that application of thiram had significant control on Fusarium wilt incidence of chickpea. The least wilt incidence was observed when thiram at $150 \%$ was used with values ranging from $1.8 \%$ to $8.9 \%$ across all growth stages. This was followed by treatment with thiram at $100 \%$ which resulted in wilt incidence ranging from $3.2 \%$ to $17.1 \%$ across all growth stages. Thiram at $50 \%$ application rate followed $100 \%$ treatment rate with wilt incidence values ranging from $4.1 \%$ to $22.8 \%$ across all growth stages. Control treatment had significantly $(\mathrm{P} \leq 0.05)$ higher wilt incidence ranging from $5.6 \%$ to $30.2 \%$ across all growth stages. Verma $^{12}$ showed that seed dress fungicides were absorbed into the plant; translocated in the plant and protected the seedlings in the field for 30days or more. Our research findings indicate that better wilt management was achieved with higher rate of application. These results were in conformity with research findings of Maitlo et al., ${ }^{9}$ who reported that increase in fungicide rate reduced wilt incidence. Muhammad ${ }^{13}$ reported a direct correlation of wilt severity to inoculum density. Fungicide application reduces the inoculum and hence low wilt incidence. Fungicide treatment eradicates seed borne pathogen and protects the seedling from infection by soil borne pathogens.

Models were developed to relate the observation on wilt incidence with the fungicide treatments (Table 2) over time (growth stage). These models were developed using MS excel software by relating wilt incidence scored with the growth stages of the crop. The rate of increase in wilt incidence over time was high under control treatment. The least rate of increase in wilt incidence was observed in the 
$150 \%$ treatment with either thiram or carbendazim; indicated by the low factor of 0.2 in Table 2. In the control treatment, wilt incidence increased by a 0.7 factor per day, which is higher than for the other treatments. Muhammad ${ }^{13}$ reported a direct correlation between wilt severity and inoculum density. Fungicide treatment has a negative effect on the inoculum density in the rhizosphere. This explains why wilt incidence varied with increasing rate of application. These results indicate that treatment using either thiram or carbendazim fungicide resulted in significant reduction in Fusarium wilt incidence of chickpea across all growth stages as compared to the control treatment. The best management was observed when $150 \%$ of either thiram or carbendazim was used. The models conform to the research findings by Maitlo et al., ${ }^{9}$ who reported that increasing fungicide rates reduced wilt incidence of chickpea thereby promoting growth of chickpea plants.

\section{Interaction effects of fungicide rates and variety on Fusarium wilt incidence}

Significant interactions were observed between the genotypes and fungicide treatments. Higher Fusarium wilt incidences were observed in Chania 2 as compared to the Chania 1 (Table 3). As the thiram or carbendazim rate was increased, wilt incidence reduced significantly $(\mathrm{P} \leq 0.05)$ in both varieties and across all growth stages. Chania 1 had lower wilt incidence as compared to Chania 2 in both season I and II. At 30 DAS, the combination of Chania 2 with control (no fungicide) treatment resulted in the highest wilt incidence of up to $7.1 \%$ and $7.8 \%$, in Seasons I and II, respectively. In season I, the combination of Chania 2 with $50 \%$ thiram or carbendazim resulted in significantly lower wilt incidence of $5.7 \%$ and $6.1 \%$ for the two fungicides, respectively. The interaction of Chania 2 with $100 \%$ of either thiram $100 \%$ or carbendazim resulted in significantly lower wilt incidence of $4.3 \%$ and $4.4 \%$, respectively. These observations were different from treatment with $50 \%$ of either fungicide and the control treatment of Chania 2 in season I. However, these interactions were not significantly different from the $4.2 \%$ wilt incidence observed for Chania I under control treatment. Chania I interaction with 50\% thiram or carbendazim rates was the next best combination; with wilt incidence of $3.4 \%$ and $3.5 \%$, respectively It was observed that genotype resistance interacted with fungicide treatment resulting in better wilt management as reflected by lower wilt incidence. Kirui et al., ${ }^{14}$ reported that Chania 1 was moderately resistant while Chania 2 was highly susceptible in greenhouse screening experiment. Treatment of Chania 2 with of thiram or carbendazim at $150 \%$ resulted in a lower wilt incidence of $2.4 \%$ and $2.6 \%$ for thiram and carbendazim, respectively, in Season I. Chania 2 and $150 \%$ treatments interactions were statistically similar to the interactions of Chania I with thiram and carbendazim at $100 \%$ rate, with values of $2.2 \%$ and $2.3 \%$, respectively for the two fungicides in season I for Chania 1. The lowest wilt incidence was observed when Chania I interacted with either thiram or carbendazim treatments at $150 \%$ rate, with wilt incidence of $1.3 \%$ and $1.7 \%$, respectively. However, if moderately resistant cultivar Chania 1 is grown, farmers could use lower rates of $100 \%$ of either thiram or carbendazim to achieve similar control/ management of less than 2.3\%; wilt incidence 30 DAS. This would be comparatively a better management option than growing the HS chickpea variety Chania 2 and treating seed with $150 \%$ fungicide rates.

Table I Effect of variety and fungicide treatment rates on Fusarium wilt incidence of Chickpea

\begin{tabular}{|c|c|c|c|c|c|c|}
\hline \multicolumn{7}{|c|}{ Disease incidence (\%) (Season I \& II) } \\
\hline Treatments & 30 DAS (I) & 30 DAS (II) & 45 DAS (I) & 45 DAS (II) & 60 DAS (I) & 60 DAS(II) \\
\hline Chania 2 & $4.70 \mathrm{a}$ & $4.60 \mathrm{a}$ & $13.68 \mathrm{a}$ & 12.79 a & $23.83 \mathrm{a}$ & $21.4 \mathrm{I} \mathrm{a}$ \\
\hline Chania I & $2.67 \mathrm{~b}$ & $2.58 \mathrm{~b}$ & $9.60 \mathrm{~b}$ & $8.53 \mathrm{~b}$ & $13.16 \mathrm{~b}$ & $11.99 \mathrm{~b}$ \\
\hline LSD & 0.5 & 0.88 & 0.8 & 2.1 & 3.19 & 2.63 \\
\hline C.V & 3.9 & 7 & 2 & 5.6 & 4.9 & 4.5 \\
\hline Control & $5.65 \mathrm{a}$ & $5.90 \mathrm{a}$ & $19.90 \mathrm{a}$ & $19.68 \mathrm{a}$ & $30.20 \mathrm{a}$ & $27.57 \mathrm{a}$ \\
\hline Thiram50\% & $4.70 \mathrm{~b}$ & $4.15 \mathrm{~b}$ & $15.95 \mathrm{~b}$ & $13.38 \mathrm{~b}$ & $22.88 \mathrm{~b}$ & $21.32 b$ \\
\hline Thiram 100\% & $3.27 \mathrm{c}$ & $3.30 \mathrm{c}$ & $9.05 \mathrm{c}$ & $8.82 \mathrm{c}$ & $17.12 \mathrm{c}$ & $15.60 \mathrm{c}$ \\
\hline Thiram 150\% & $1.83 \mathrm{e}$ & $1.80 \mathrm{~d}$ & $5.18 \mathrm{~d}$ & $4.87 \mathrm{~d}$ & $8.92 \mathrm{~d}$ & $7.87 \mathrm{~d}$ \\
\hline Carbendazim50\% & $4.82 \mathrm{~b}$ & $4.42 \mathrm{~b}$ & $16.48 \mathrm{~b}$ & $13.82 \mathrm{~b}$ & $23.12 b$ & $21.67 \mathrm{~b}$ \\
\hline Carbendazim $100 \%$ & $3.35 \mathrm{c}$ & $3.43 c$ & $9.45 \mathrm{c}$ & $8.95 \mathrm{c}$ & $18.17 \mathrm{c}$ & $14.57 \mathrm{c}$ \\
\hline Carbendazim I 50\% & $2.15 \mathrm{~d}$ & $2.11 \mathrm{~d}$ & $5.45 \mathrm{~d}$ & $5.10 \mathrm{~d}$ & $9.08 \mathrm{~d}$ & $8.33 \mathrm{~d}$ \\
\hline LSD & 0.27 & $0.4 I$ & 0.93 & 0.78 & 1.15 & 1.18 \\
\hline C.V & 6.1 & 9.6 & 6.7 & 6.1 & 5.2 & 7.7 \\
\hline
\end{tabular}

*Means followed by the same letter(s) in a column are not significantly different $(\mathrm{P}<0.05)$. 
Table 2 Functional relationship between Fusarium wilt incidence and growth stage

\begin{tabular}{lll}
\hline Treatment & Function & R2 \\
\hline Control & $y=0.77 x-16.5$ & 0.98 \\
Carbendazim50\% & $y=0.59 x-12.6$ & 0.98 \\
Thiram50\% & $y=0.58 x-12.7$ & 0.99 \\
Carbendazim 100\% & $y=0.43 x-9.8$ & 0.99 \\
Thiram 100\% & $y=0.43 x-10.0$ & 0.99 \\
Carbendazim|50\% & $y=0.22 x-4.5$ & 0.99 \\
Thiram 150\% & $y=0.22 x-4.8$ & 0.99
\end{tabular}

Table 3 Interaction of thiram or carbendazim with two chickpea varieties on Fusarium wilt incidence

\begin{tabular}{|c|c|c|c|c|c|c|c|c|c|c|c|c|}
\hline Treatment & $\begin{array}{l}30 \\
\text { DAS_I }\end{array}$ & & $\begin{array}{l}30 \\
\text { DAS_II }\end{array}$ & & $\begin{array}{l}45 \\
\text { DAS_I }\end{array}$ & & $\begin{array}{l}45 \\
\text { DAS_II }\end{array}$ & & $\begin{array}{l}60 \\
\text { DAS_I }\end{array}$ & & $\begin{array}{l}60 \\
\text { DAS_II }\end{array}$ & \\
\hline & $\begin{array}{l}\text { Chan } \\
2\end{array}$ & $\begin{array}{l}\text { Chan } \\
\text { I }\end{array}$ & Chan2 & Chan I & Chan2 & Chan I & Chan2 & Chan I & Chan2 & Chan I & Chan2 & Chan I \\
\hline Control & $7.1 \mathrm{a}$ & $4.2 c$ & $7.7 \mathrm{a}$ & $4.0 c$ & $23.1 \mathrm{a}$ & $16.7 \mathrm{c}$ & $21.1 \mathrm{a}$ & $18.3 b$ & $41.2 \mathrm{a}$ & $19.2 \mathrm{~cd}$ & $36.9 \mathrm{a}$ & $18.2 \mathrm{c}$ \\
\hline Thiram50 & $6.0 \mathrm{~b}$ & $3.4 d$ & $5.2 b$ & $3.1 d$ & $18.1 \mathrm{~b}$ & 13.8d & $16.4 \mathrm{bc}$ & $10.4 \mathrm{~d}$ & $29.2 b$ & $16.6 \mathrm{e}$ & $27.0 \mathrm{~b}$ & $15.6 \mathrm{~d}$ \\
\hline Thiram I00 & $4.3 c$ & $2.2 \mathrm{e}$ & $4.3 c$ & $2.3 \mathrm{e}$ & II.Ie & $7.0 f$ & $11.3 \mathrm{~d}$ & $6.3 e$ & $21.2 \mathrm{c}$ & $13.0 f$ & 19.1c & 12.1e \\
\hline Thiram I 50 & $2.4 \mathrm{e}$ & $1.3 \mathrm{f}$ & $2.4 \mathrm{e}$ & $1.2 \mathrm{f}$ & 6.If & $4.2 \mathrm{~g}$ & $6.1 \mathrm{e}$ & $3.7 f$ & $10.8 \mathrm{fg}$ & $7.0 \mathrm{~h}$ & $10.8 \mathrm{e}$ & $4.9 f$ \\
\hline Carbendazim50 & $6.1 \mathrm{~b}$ & $3.5 \mathrm{~d}$ & $5.5 b$ & $3.3 \mathrm{~d}$ & $18.8 \mathrm{~b}$ & I4.Id & $17.2 b$ & $10.5 \mathrm{~d}$ & $29.7 b$ & $16.5 \mathrm{e}$ & $27.8 b$ & $15.6 \mathrm{~d}$ \\
\hline Carbendazim I 00 & $4.4 c$ & $2.3 e$ & $4.5 c$ & $2.4 \mathrm{e}$ & $11.7 \mathrm{e}$ & $7.2 f$ & $1 \mathrm{I} .2 \mathrm{~d}$ & $6.7 e$ & $22.7 c$ & $13.6 f$ & $16.8 \mathrm{~cd}$ & $12.4 \mathrm{e}$ \\
\hline Carbendazim I 50 & $2.6 \mathrm{e}$ & I.7f & $2.6 \mathrm{e}$ & $1.6 \mathrm{f}$ & $6.7 f$ & $4.2 \mathrm{~g}$ & $6.3 e$ & $3.9 f$ & $12.0 f$ & 6.17 & $11.5 \mathrm{e}$ & $5.2 f$ \\
\hline LSD & 0.44 & & 0.73 & & 1.3 & & 1.62 & & 2.45 & & 2.44 & \\
\hline
\end{tabular}

Means followed by the same letter(s) in the same column are not significantly different at $\mathrm{P}<0.05$ LSD.

At 45 DAS, the highest wilt incidence $23.1 \%$ and $21.1 \%$ were observed with Chania 2 under control treatment for season I and II, respectively,. At 45 DAS, Chania 2 under thiram or carbendazim at $50 \%$ rate of application resulted in $18.1 \%$ and $18.8 \%$ wilt incidence, respectively in season I. t 45 DAS, Chania 1 control treatment had lower wilt incidence than Chania 2 at either treatment with $50 \%$ thiram or $50 \%$ carbendazim (Table 3 ) with $16.7 \%$ wilt incidence in season I. At 45 DAS, treatment of Chania I with either thiram or carbendazim at $50 \%$ resulted in lower wilt incidence of $13.8 \%$ and $14.1 \%$, respectively, in season I. These interactions were better in wilt management as compared to application of the same rate of fungicides to Chania 2. A similar. At 45 DAS, interaction of Chania 2 with thiram or carbendazim at $100 \%$ resulted in lower wilt incidence values of $11.1 \%$ and $11.7 \%$ which were significantly different from other treatment interactions. Seed treatment of Chania 2 with $150 \%$ of either thiram or carbendazim resulted in $6.1 \%$ and $6.7 \%$, Fusarium wilt incidence, respectively. This was similar to application of thiram or carbendazim at $100 \%$ to Chania 1 which resulted in $7.0 \%$ and $7.2 \%$ Fusarium wilt incidence, respectively,. A similar trend was observed in
Season II at 45 DAS. The lowest fusarium wilt incidence was observed when Chania 1 was treated with either thiram or carbendazim at $150 \%$ which resulted in $4.2 \%$ Fusarium wilt incidence. During season II, lower wilt incidence of $3.7 \%$ and $3.9 \%$ were observed in Chania 1 treated with thiram and carbendazim, respectively (Table 3 ).

At 60 DAS, Chania 2 under control treatment had $41.2 \%$ and $36.9 \%$ wilt incidence in seasons I and II, respectively. At 60 DAS, Significant interaction occurred between Chania 2 and thiram or carbendazim at $50 \%$, with $29.2 \%$ and $29.7 \%$ wilt incidence, respectively, in season I. At 60 DAS, Treatment of Chania 2 with $100 \%$ of either thiram or carbendazim resulted in a wilt incidence of $21.2 \%$ and $22.7 \%$, respectively. These values were similar to the wilt incidence of Chania I under control treatment. Application of thiram or carbendazim at $50 \%$ to Chania I resulted in significantly lower wilt incidence, of $16.6 \%$ and $16.5 \%$, respectively 60 DAS. Treatment of Chania 2 with either thiram or carbendazim at $150 \%$ resulted in lower wilt incidence compared to treating the same variety with the other treatment rates $(0 \%, 50 \%$ and $100 \%)$, with wilt incidence of $10.8 \%$ and $12.0 \%$ being observed for thiram and carbendazim, respectively, at 60 DAS. 
These observations were similar to Chania I treated with either thiram or carbendazim at $100 \%$ giving wilt incidence values of $13.0 \%$ and $13.6 \%$ for thiram and carbendazim, respectively in season I. From these results, it was inferred that moderately resistant Chania 1 needed less chemical treatment as compared to the HS Chania 2 at 60 DAS. The interaction between Chania I with either thiram or carbendazim at $150 \%$ resulted in lower Fusarium wilt incidence of $7.0 \%$ and $6.2 \%$, respectively in season I; and $4.9 \%$ and $5.2 \%$, respectively in season II at 60 DAS.

\section{Conclusion}

Low wilt incidence was observed in moderately resistant variety Chania 1 as compared to highly susceptible Chania 2. Fusarium wilt incidence was lowest when chickpea was seed dressed with $150 \%$ $(2.25 \mathrm{~g} / \mathrm{kg}$ seed $)$ of either thiram or carbendazim fungicide at all growth stages, followed by treatment with $100 \%$ of either thiram or carbendazim especially when growing (highly) susceptible varieties. Interactions observed indicate that using moderately resistant variety required much less fungicide treatment to control Fusarium wilt as compared to planting highly susceptible Chania 2.

\section{Acknowledgements}

None.

\section{Conflict of interest}

The author declares no conflict of interest.

\section{References}

1. Nielson DC. Production functions of chickpea, field pea, and lentil in the central great plains. Agronomy Journal. 2001;93:193-197.

2. Oweis T, Hachum A, Pala M. Water use efficiency of winter sown chickpea under supplemental irrigation in a Mediterranean environment. Water resources management. 2004;66(2):163-179.

3. Kamithi DK, Kibe AM, Akuja T. Effect of Nitrogen and plant population on Dry matter production of Desi Chickpea (CicerarietinumL.) in a dry land at Naivasha, Kenya. Egerton journal of science and technology. 2008;8:104-117.

4. Kibe AM, Onyari CN. Production functions and their use in predicting chickpea biomass yields in Naivasha Kenya. Egerton journal of science and technology. 2008;2(4):514-519.

5. Kibe AM, Kamithi DK. Production potential of Desi chickpea grown under various Nitrogen and plant population Densities at Naivasha Kenya. Egerton Journal of Spec. 2007;2(4):1-14

6. Haware MP, Nene YL, Pundir RPS, et al. Screening world chickpea germplasm for resistance to Fusarium wilt. Field crops Research. 1992;30(1-2):147-167.

7. Pande S, Gaur PM, Sharma M, et al. Identification of single and multiple resistance in Desi chickpea genotypes to Ascochyta blight, Botrytis gray mould and Fusarium wilt. An open access journal by ICRISAT. 2007.

8. Wagara IN. Molecular and virulence characterization of Phaeoisariopsis griseola and reaction of bean cultivars to races of angular leaf spot. $\mathrm{PhD}$ Thesis, University of Nairobi; 2005. 166 p.

9. Maitlo SA, Syed RN, Rustamani MA, et al. Comparative efficacy of different fungicides against Fusarium wilt of chickpea (Cicer arietinum L.). Pak J Bot. 2014;46(6):2305-2312.

10. Nikam PS, Jagtap GP, Sontakke PL. Management of chickpea wilt caused by Fusarium oxysporum f. sp. ciceris African. Journal of Agricultural Research. 2007;2 (12):692-697.

11. Singh K, Singh AK, Singh RP (2004) Effect of fungicidal seed treatment on the fungi associated with chickpea. Annals of Plant-ProtectionSciences. 12(2):450-451.

12. Verma RK. Chemotherapeutic activity of five systemic fungicides in gram seedlings against three soil borne pathogens. Msc. Thesis, Jabalpur, India: JN Agricultural University; 1976.

13. Muhammad AA. Variability in Fusarium oxysporum $f$. sp. Ciceris for Chickpea Wilt resistance in Pakistan. Phd Thesis submitted to Quaid-iAzam University, Islamabad. Department of Microbiology, Faculty of Biological Sciences; 2010.

14. Kirui KR, Kibe AM, Wagara IN, et al. Screening of chickpea genotypes for resistance to Fusarium wilt and its management with fungicides. Msc. Thesis, Egerton University, Faculty of Agriculture, CHS Department; 2015 . 